\title{
Pathway for Biodegrading Nodularin (NOD) by Sphingopyxis sp. USTB-05
}

\author{
Nan Feng ${ }^{1,+}$, Fan Yang ${ }^{1,+}$, Hai Yan ${ }^{1, *}$, Chunhua Yin ${ }^{1}$, Xiaolu Liu ${ }^{1}$, Haiyang Zhang ${ }^{1}$, \\ Qianqian $\mathrm{Xu}^{1}{ }^{1}, \mathrm{Le} \mathrm{Lv}^{1}$ and Huasheng Wang ${ }^{2}$ \\ 1 School of Chemistry and Biological Engineering, University of Science and Technology Beijing, \\ Beijing 100083, China; ustbnanfeng@163.com (N.F.); ustbyangfan@163.com (F.Y.); chyin@ustb.edu.cn (C.Y.); \\ xiaoluliu@ustb.edu.cn (X.L.); zhanghy@ustb.edu.cn (H.Z.); qianqianxu@ustb.edu.cn (Q.X.); \\ lvle@ustb.edu.cn (L.L.) \\ 2 School of Architectural and Surveying \& Mapping Engineering, Jiangxi University of Science and Technology, \\ Ganzhou 341000, China; wanghuasheng2005@126.com \\ * Correspondence: haiyan@ustb.edu.cn; Tel.: +86-10-6233-3177 \\ + These authors contributed equally to this work.
}

Academic Editor: Luis M. Botana

Received: 27 January 2016; Accepted: 13 April 2016; Published: 4 May 2016

\begin{abstract}
Nodularin (NOD) is greatly produced by Nodularia spumigena and released into the environment when toxic cyanobacterial blooms happened in natural water body, which is seriously harmful to human and animals. The promising bacterial strain of Sphingopyxis sp. USTB-05 was found to have an ability in biodegrading NOD. Initially, $11.6 \mathrm{mg} / \mathrm{L}$ of NOD could be completely eliminated within $72 \mathrm{~h}$ by whole cells of USTB- 05 , and within $36 \mathrm{~h}$ by its crude enzymes (CEs) of $570 \mathrm{mg} / \mathrm{L}$, respectively. During the enzymatic biodegradation process of NOD, two products were observed on the profiles of HPLC. Based on the analysis of $m / z$ ratios of NOD and its two products on a rapid-resolution liquid chromatogram-mass spectrum (RRLC-MS), we suggested that at least two enzymes of USTB-05 participated in biodegrading NOD. The first enzyme hydrolyzed Arg-Adda peptide bond of cyclic NOD and converted it to linear NOD as the first product. The second enzyme was found to cut off the target peptide bond between Adda and Glu of linearized NOD, and Adda was produced as a second and dead-end product. This finding is very important in both basic research and the application of USTB-05 on the removal of NOD from a water environment.
\end{abstract}

Keywords: nodularin (NOD); Sphingopyxis sp. USTB-05; crude enzymes (CEs); biodegradation pathway

\section{Introduction}

There is a drastically increasing trend for the breakout of harmful cyanobacterial blooms in recent decades, posing a serious threat to the natural ecological system. One of the biggest hazards of cyanobacterial blooms is to produce and to release various kinds of microalgal toxins, in which toxic cyclic peptides, such as microcystins (MCs) and nodularin (NOD), are most frequently detected all over the world [1]. NOD is a cyclic pentapeptide hepatotoxin produced by the filamentous cyanobacterium Nodularia spumigena, which is usually found in brackish water, such as the Baltic Sea [2], Lakes Alexandrina and Albert in South Australia [3], and brackish lakes or lagoons [4,5]. Furthermore, the nodularin variants (L-Har2) produced in freshwater have also been reported [6]. NOD shows a potent acute hepatotoxicity and tumor-promoting activity in domestic animals and humans by inhibition of the eukaryotic proteins phosphatase 1 and 2A [7]. Furthermore, NOD has also been proven to be not only a tumor promoter, but also a tumor initiator [8]. The $\mathrm{LD}_{50}$ value of NOD is approximately 50 $\mu \mathrm{g} / \mathrm{kg}$ body weight (intraperitoneal mouse) [9]. The incidents of animal poisoning and human health problems resulted from toxic blooms of Nodularin spumigena have been well documented [5,10-12]. 
NOD is a compound of monocyclic pentapeptide consisting of cyclo[-D-erythro- $\beta$-methylAsp (iso-linkage)-L-Arg-Adda-D-Glu(iso-linkage)-Mdhb], where Mdhb stands for $N$ methyldehydrobutyrine and Adda is the particular C20 $\beta$-amino acid: (2S,3S,8S,9S)-3-amino-9methoxy-2,6,8-trimethyl-10-phenyldeca-4(E),6(E)-dienoic acid. NOD closely resembles to MCs with respect to structure and biological activity [13]. There have been nine different analogues of NOD documented to date, varying usually by the variable arginine and the degree of methylation and stereochemistry $[14,15]$. NOD is water-soluble and chemically stable owing to its cyclic structure and the existence of several special amino acids [16], which is recalcitrant to treatments such as boiling, chemical hydrolysis and oxidation at near neutral $\mathrm{pH}$ [15]. Bioremediation is considered to be one of the most eagerly anticipated biotechnologies that holds promise for a successful and cost effective solution for removing NOD from water without damaging the natural environment. Some bacterial strains of Sphingomonas sp. [17], Paucibacter toxinivorans [16], and Brevibacterium sp. [18] have abilities to biodegrade MCs and NOD. The pathways [19], enzymes, and genes [19-21] which are responsible for the biodegradation of MCs, have been widely investigated, but less information was reported on the pathway for biodegrading NOD, although it is also frequently present.

In 2010, a MC-degrading bacterium designated USTB-05 was isolated from Dianchi Lake and found to be capable of biodegrading MC-RR, which was identified as Sphingopyxis sp. by the analysis of 16S rDNA (GenBank database under accession number: EF607053) [22]. Furthermore, MC-LR and MC-YR could also be totally removed by USTB-05 and its crude enzymes (CEs) $[23,24]$, indicating that USTB-05 indeed possesses a strong ability in biodegrading MCs. Enzymatic pathways for biodegrading MC-RR, MC-LR, and MC-YR by USTB-05 have also been elucidated [22-24].

Here, we found that NOD could be biodegraded by both whole cells of USTB-05 and its CEs. One intermediate and one dead-end product of NOD catalyzed by CEs were observed on the profiles of HPLC with time course, indicating that at least two enzymes were involved in the biodegradation of NOD. These findings are of vital importance for both the basic study and the practical application in the removal of NOD by USTB-05 from natural water sources.

\section{Results}

\subsection{Biodegradation of NOD by Sphingopyxis sp. USTB-05}

Figure 1 shows the biodegradation kinetics of NOD by USTB-05 and demonstrates that the initial concentration of $11.6 \mathrm{mg} / \mathrm{L}$ NOD was completely eliminated within $72 \mathrm{~h}$ while NOD in the control group remained almost constant. The average biodegradation rate of NOD was $3.9 \mathrm{mg} / \mathrm{L}$ per day, indicating that USTB-05 has a strong ability in removing NOD.

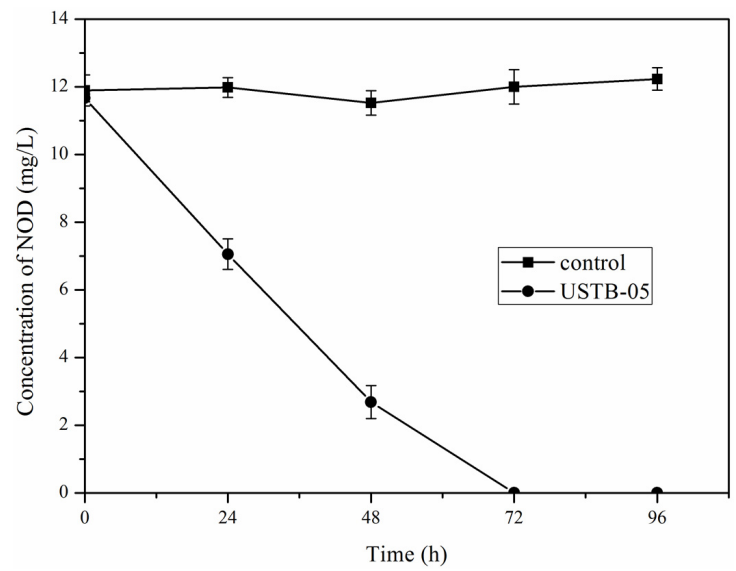

Figure 1. Biodegradation kinetics of NOD by whole cells of Sphingopyxis sp. USTB-05. Biomass of strain USTB-05 with an optical density at $600 \mathrm{~nm}\left(\mathrm{OD}_{600}\right)$ of $0.5 \pm 0.02$ was used. Standard errors are displayed $(n=3)$. 


\subsection{Enzymatic Kinetics of the NOD Biodegradation by CEs of USTB-05}

Figure 2 demonstrates the biodegradation kinetics of NOD catalyzed by CEs of USTB-05 containing different protein concentrations of 211,380 and $570 \mathrm{mg} / \mathrm{L}$, respectively, which indicated that the removal rate of NOD was greatly improved with the increase of protein content. The initial concentration of $11.6 \mathrm{mg} / \mathrm{L}$ of NOD could becompletely eliminated within $36 \mathrm{~h}$ when the protein concentration was $570 \mathrm{mg} / \mathrm{L}$, while NOD in control group remained also almost constant. Compared with the cells of USTB-05 (Figure 1), its CEs showed a higher biodegradation rate.

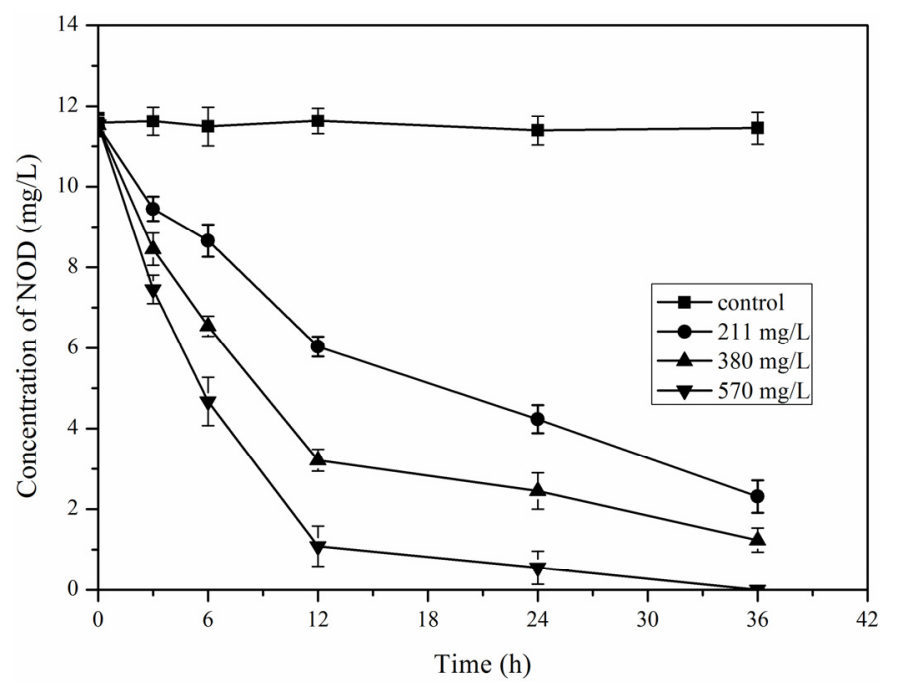

Figure 2. Biodegradation kinetics of NOD catalyzed by CEs containing different protein concentrations. Standard errors are displayed $(n=3)$.

\subsection{Products of NOD Detected at the Wavelength of $238 \mathrm{~nm}$ on HPLC}

Figure 3 shows the biodegradation products of NOD in the presence of CEs ( $570 \mathrm{mg} / \mathrm{L}$ protein) detected on HPLC. The peak of NOD at the retention time of 13.5 min gradually decreased over time, and completely disappeared at $36 \mathrm{~h}$ (Figure 3). A new peak of product $\mathrm{A}$ at the retention time of $7.2 \mathrm{~min}$ appeared at $3 \mathrm{~h}$ (Figure 3b), increased (from Figure 3b-d), and then decreased (Figure 3e,f). As shown in Figure 3c, another new peak of product B at the retention time of $19.2 \mathrm{~min}$ appeared at $6 \mathrm{~h}$ and always increased over time until $36 \mathrm{~h}$. The ultraviolet absorption spectra of both peak A and B were very similar to that of NOD in the wavelength from $200 \mathrm{~nm}$ to $370 \mathrm{~nm}$ (Figure $3 \mathrm{~b}$,e) suggesting that Adda was still present in these two products. The results indicate that CEs of USTB-05 has the enzymatic activity to catalyze NOD. The first intermediate of NOD is product A (retention time of $7.2 \mathrm{~min}$ ). Afterwards, product A is completely converted to product B (retention time of $19.2 \mathrm{~min}$ ). 

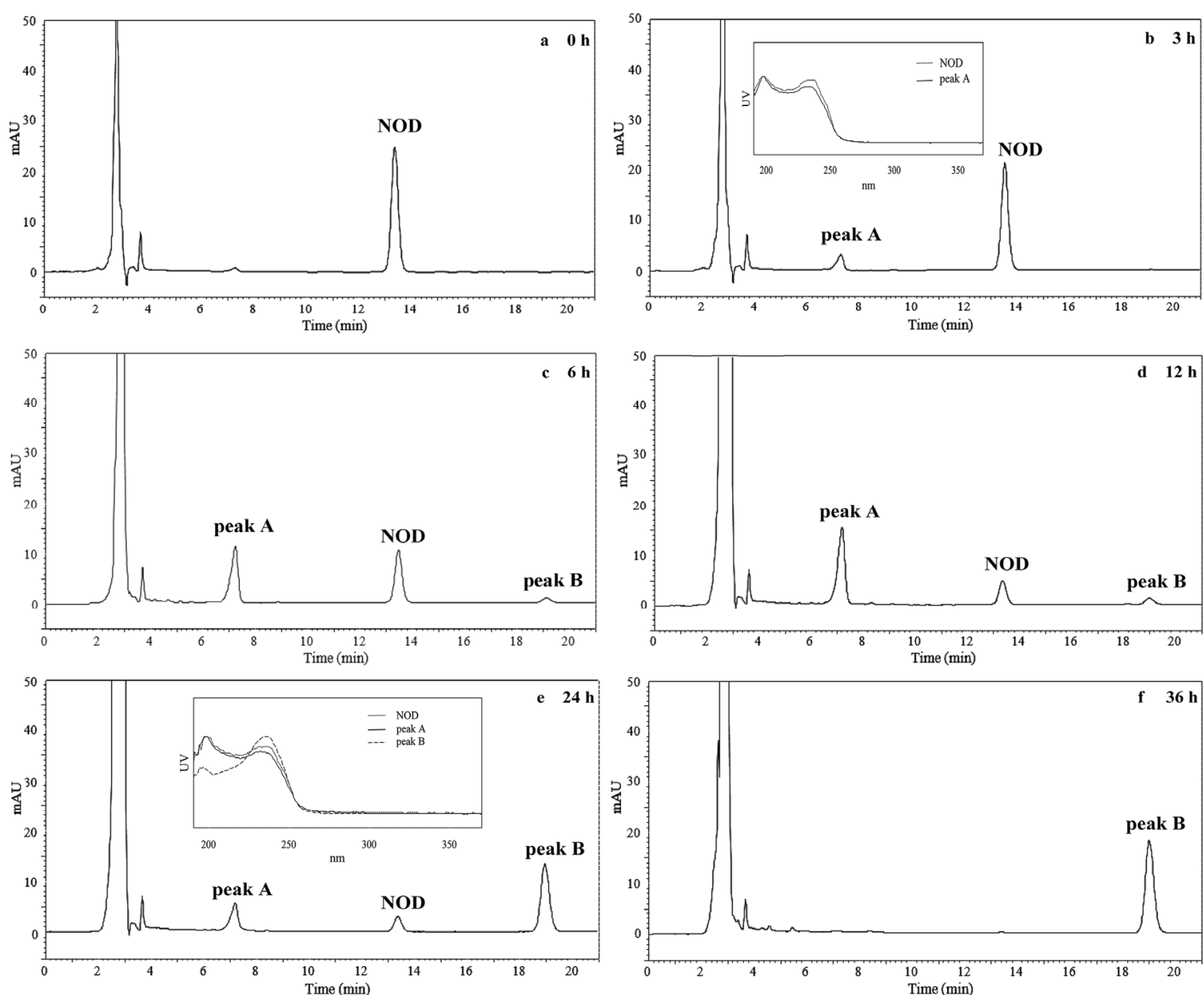

Figure 3. High performance liquid chromatography (HPLC) profiles for the enzymatic biodegradation of NOD by CEs after the following times: (a) 0 h; (b) 3 h; (c) 6 h; (d) 12 h; (e) 24 h; and (f) 36 h. The scanning profiles of NOD and its products at the ultraviolet wavelength from $200 \mathrm{~nm}$ to $370 \mathrm{~nm}$ are shown in $(\mathbf{b}, \mathbf{e})$.

\subsection{RRLC-MS Analysis of NOD and Its Biodegradation Products}

HPLC analysis of samples containing CEs of USTB-05 revealed the presence of two biodegradation products and showed that the absorption spectra of the two products were extremely similar to that of NOD. Based on the retention time and UV chromatogram in the HPLC profiles, peaks at the retention times of 13.5, 7.2, and 19.2 min were identified as NOD, product $\mathrm{A}$, and product $\mathrm{B}$, respectively. To characterize the products, RRLC-MS was used to measure the mass/charge $(\mathrm{m} / z)$ ratios of NOD and its two products. The mass spectral analysis of NOD showed a major ion at $m / z 825.4$, corresponding to the $[\mathrm{M}+\mathrm{H}]^{+}$protonated molecular ion (Figure $4 \mathrm{a}$ ). 

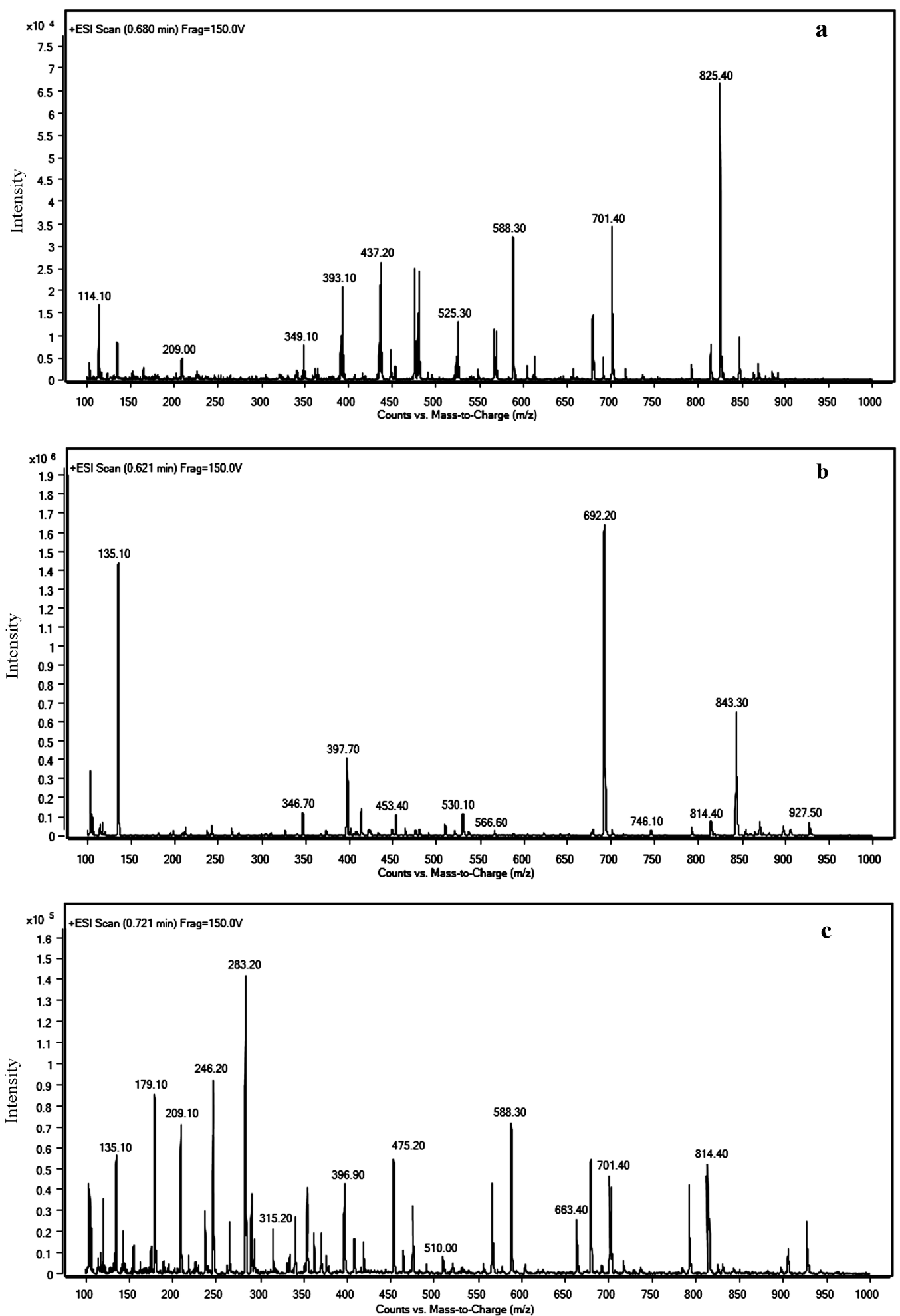

Figure 4. RRLC-MS profile for NOD and its biodegradation products: (a) MS spectrum for NOD; (b) MS spectrum for product A; and (c) MS spectrum for product B.

The mass spectrum for product A showed a protonated molecular ion at $m / z 843.4$ and a prominent ion at $m / z 692.2$ (Figure $4 \mathrm{~b}$ ). An ion peak at $m / z 843.4$ indicates that product $\mathrm{A}$ was linearized NOD $\left[\mathrm{M}+\mathrm{H}_{2} \mathrm{O}+\mathrm{H}\right]^{+}$. The major peak with $m / z 692.2\left[\mathrm{M}+\mathrm{H}_{2} \mathrm{O}-151+\mathrm{H}\right]^{+}$is $m / z 151$ lower than that of linearized NOD, which corresponds to the loss of terminal phenylethymethoxy group $\left(\mathrm{PhCH}_{2} \mathrm{CHOCH}_{3}, \mathrm{MW}\right.$ : 135) and the amino $\mathrm{NH}_{2}$ group (MW: 16) from Adda after Arg-Adda 
bond breaking. This is a typical loss fragment from a linear NOD with Adda due to the radical fragmentation rearrangement [25]. The presence of this peak evidences that the linearized NOD product contained $N$-terminal Adda. Moreover, the presence of carboxy-terminal arginine (Arg) was demonstrated by protonated ion $m / z 530.1$ [Glu-Mdhb-MeAsp-Arg-OH $+2 \mathrm{H}]^{+}$(Figure 4b).

Figure $4 \mathrm{c}$ reveals that the protonated molecular ion of product B was detected at $m / z 663.4$, which coincides with the dimeric ion of Adda (MW: 331) [26,27]. Additionally, fragments at $m / z 315.2$ and $m / z 135.1$ are related to the loss of the amino $\mathrm{NH} 2$ group (MW: 16) from Adda and the $\mathrm{PhCH} 2 \mathrm{CHOCH}_{3}$ part of Adda, respectively. Other fragment ions that support the elucidation of the structure of product $\mathrm{B}$ were recorded at $\mathrm{m} / \mathrm{z} 283.2$ [Adda $\left.-\mathrm{NH}_{3}-\mathrm{CH}_{3} \mathrm{OH}+\mathrm{H}\right]^{+}$and 179.1 [Adda $-\mathrm{PhCH}_{2} \mathrm{CHOCH}_{3}-$ $\left.\mathrm{NH}_{3}+\mathrm{H}\right]^{+}$. Therefore, it is inferred that product B was Adda.

\section{Discussion}

MCs and NOD are common organic contaminants in natural eutrophic lakes and reservoirs around the world and there is an urgent need for an efficient and low-cost technology to eliminate cyanobacterial toxins from drinking water. Biodegradation has been found to be one of the essential processes for removing cyanotoxins. Both a microbial community [28] and the single bacterial strain [29,30] were confirmed to be capable of biodegrading MCs. It has also been revealed that biodegradation of NOD by an indigenous bacterial community is the main pathway of this toxin's removal [26,27,31]. However, a lag phase that lasted from two days to three weeks was present in the biodegradation process before the rapid decomposition of this toxin. It is universally known that the enzymes degrading cyanobacterial peptide toxins possess substrate-specificity and, thus, not all MC-degrading bacteria can hydrolyze peptide bonds in NOD [19,29]. So far, the number of bacterial species reported to be capable of degrading NOD is very limited $[16,17,32]$ and less information was avaiable on NOD, although it was also frequently found in natural water body. Sphingomonas sp. $7 \mathrm{CY}$, isolated from Lake Suwa in Japan, has been reported to biodegrade NOD-Har containing the homoarginine residue in place of arginine of NOD, but only in the presence of MC-RR [33]. Thirteen bacterial strains isolated from sediments and water of Finnish lakes [16] and five bacteria isolates from three Scottish waters [18] were found to have the abilities in biodegrading both MCs and NOD, but the degradation rates were considerably slow. Cell extract from Sphingomonas sp. B-9 (Lake Tsukui, Kanagawa, Japan) was also found to remove NOD, but only Adda was detected as a final product [17].

As for the biodegradation products of NOD, Kato et al. (2007) confirmed that NOD could be biodegraded by CEs of strain B-9 and linear NOD and Adda were identified as a degradation intermediate and a final product, respectively [32]. Mazur-Marzec et al. (2009) conducted regular studies on Gulf of Gdańsk, southern Baltic Sea, which experienced high blooms of toxic cyanobacteria [26]. In their study, incubation of NOD in the presence of sediments from the Gulf of Gdańsk resulted in the formation of several products of microbial degradation including a linear NOD, Adda, and two tetrapeptides: H-Adda-Glu-Mdhb-MeAsp-OH and H-Glu-Mdhb-MeAsp-Arg-OH. The results confirmed that various biodegradation pathways of NOD are possible. Based on the successful isolation and identification of Sphingopyxis sp. USTB-05 for the biodegradation of MC-RR [22], we have continuously investigated its genes and enzymes involved in biodegrading MC-RR, MC-LR, and MC-YR, and three biodegradation genes have been firstly cloned and expressed [24,34,35]. The first enzyme, microcystinase (coded by the gene USTB-05-A), can turn the highly-stable cyclic MC-LR, MC-RR or MC-YR into a linear structure by the hydrolytic cleavage between Adda and Arg. The second enzyme, serine protease (coded by the gene USTB-05-B), is responsible for converting linearized MC-LR, MC-RR, or MC-YR into the tetrapeptide of $\mathrm{NH}_{2}$-Adda-Glu (iso)-Mdha-Ala-OH. The third enzyme, peptidase (coded by the gene USTB-05-C), plays a role in cleaving the tetrapeptide to produce Adda $[24,34,35]$. Compared with MCs, all of which contain seven amino acids, NOD is a much tighter and smaller ring with only five amino acids and it has been indicated that this makes it harder to open the ring structure to facilitate degradation [18]. According to our study, an initial 11.6 mg/L of NOD was completely eliminated by USTB-05 and its CEs within $72 \mathrm{~h}$ and $36 \mathrm{~h}$, respectively (Figures 1 
and 2). In order to investigate the biodegradation pathway of NOD, Adda with the conjugated diene in NOD was traced, and two biodegradation products were successfully observed with the time course at the wavelength of $238 \mathrm{~nm}$ on the HPLC profiles (Figure 3). Both products characterized by the UV absorption spectra were similar to NOD.

Successful analysis of mass/charge $(\mathrm{m} / \mathrm{z})$ ratio of NOD and its two products by RRLC-MS provided evidences for the biodegradation pathway of NOD by Sphingopyxis sp. USTB-05 (Figure 4). The first enzyme was active in cleaving the target peptide bond between Arg and Adda of NOD $\left(m / z\right.$ 825) and converting cyclic NOD to linear NOD $\left(\mathrm{NH}_{2}-\right.$ Adda-Glu-Mdhb-MeAsp-Arg-OH) $(m / z$ 843, product $\mathrm{A})$ as the intermediate product. Then, the second enzyme was found to cut off the target peptide bond between Adda and Glu of linearized NOD, producing Adda $(m / z 663$, product B) as the final product (Figure 5). Generally, the biodegradation pathway of NOD by USTB-05 was similar to that of MC-RR, LR, and YR, as we have reported previously [14,22-24]. These findings might provide valuable evidence for further investigation on the biodegradation mechanism of NOD and its analogues by Sphingopyxis sp. USTB-05.

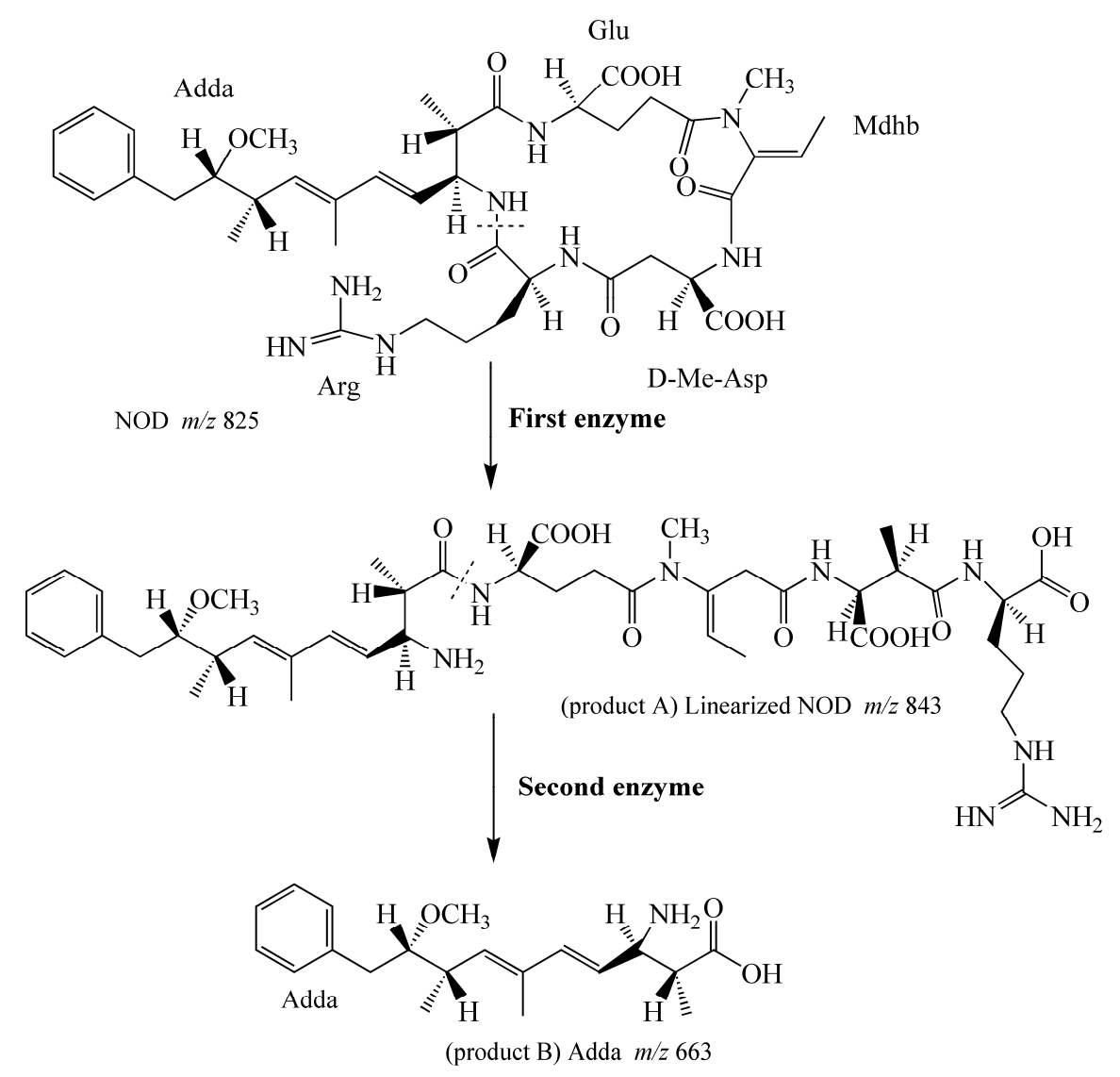

Figure 5. Proposed biodegradation pathway of NOD by Sphingopyxis sp. USTB-05.

\section{Conclusions}

Based on the isolation of the promising bacterial strain Sphingopyxis sp. USTB-05 for the biodegradation of MCs, we successfully investigated its enzymatic biodegradation pathway on NOD. Firstly, an initial NOD amount of $11.6 \mathrm{mg} / \mathrm{L}$ was completely biodegraded within $72 \mathrm{~h}$ and $36 \mathrm{~h}$ by USTB-05 and its CEs containing $570 \mathrm{mg} / \mathrm{L}$ protein, respectively. Secondly, two products of NOD were observed on HPLC profiles at the wavelength of $238 \mathrm{~nm}$ during the biodegradation of NOD catalyzed by CEs. Both NOD and its two products were found to have similar UV scanning profiles at wavelengths from 200 to $370 \mathrm{~nm}$, indicating that the group of Adda in products of NOD remained intact. Thirdly, the enzymatic biodegradation pathway of NOD by Sphingopyxis sp. USTB-05 was 
suggested. The first enzyme was active in cleaving the target peptide bond between Arg and Adda of NOD and converting cyclic NOD to linear NOD as the first product. Then the second enzyme was found to cut off the target peptide bond between Adda and Glu of linearized NOD resulting in the formation of Adda as the final product. This study is crucial, not only basic research, but also as a promising approach to remove NOD in future water treatment strategies.

\section{Materials and Methods}

\subsection{Chemicals}

Standard NOD ( $\geqslant 95 \%$ purity, molecular formula: $\mathrm{C}_{41} \mathrm{H}_{60} \mathrm{~N}_{8} \mathrm{O}_{10}, \mathrm{MW}: 824$, Enzo Science Inc., New York, NY, USA) of $500 \mu \mathrm{g}$ was dissolved in deionized water at a $100 \mathrm{mg} / \mathrm{L}$ concentration and stored at $-20{ }^{\circ} \mathrm{C}$ until use. Chromatographic grade acetonitrile was used to prepare the mobile phase in HPLC and RRLC-MS analyses. All other chemicals used in this study were analytical grade except those specified by the kits.

\subsection{Bacterial Strain and Cultural Conditions}

A promising bacterial strain of Sphingopyxis sp. USTB-05 was used as previously described [22]. The culture medium was used as mentioned in the previous report [22]. The prepared medium was sterilized at $121^{\circ} \mathrm{C}$ for $20 \mathrm{~min}$ and then the medium was inoculated with USTB-05. The bacterial strain was cultured at $30^{\circ} \mathrm{C}$ and $200 \mathrm{r} / \mathrm{min}$.

\subsection{Preparation for the Crude Enzymes (CEs) of Sphingopyxis sp. USTB-05}

Bacterial cells of USTB-05 in the logarithmic growth phase of the third day were harvested by centrifugation at $8000 \mathrm{r} / \mathrm{min}$ for $20 \mathrm{~min}$ at room temperature. The bacterial pellet was subsequently washed three times with $50 \mathrm{mM}$ phosphate buffer solution (PBS, pH 7.0). Afterwards, the cells were resuspended in $30 \mathrm{~mL}$ PBS, and then disrupted using an ultrasonic disruptor with an output power of $600 \mathrm{~W}$ for $15 \mathrm{~min}$ in an ice bath. The cell debris was removed by centrifugation $(13,000 \mathrm{r} / \mathrm{min}$, $30 \mathrm{~min}, 4^{\circ} \mathrm{C}$ ) and the supernatant was collected and used as CEs for the enzymatic biodegradation of NOD. The concentration of protein in CEs was $760 \mathrm{mg} / \mathrm{L}$ determined with the Bradford Protein Quantification Kit (Beijing Solarbio Science and Technology Co., Ltd., Beijing, China).

\subsection{NOD-Biodegrading Activity of Sphingopyxis sp. USTB-05}

The bacterial cells of USTB-05 in the logarithmic growth phase of the third day $\left(\mathrm{OD}_{600}=1.0 \pm 0.05\right)$ were harvested by centrifugation $(8000 \mathrm{r} / \mathrm{min}, 15 \mathrm{~min})$, washed three times with $50 \mathrm{mM}$ PBS (pH 7.0), and resuspended into $2 \mathrm{~mL}$ mineral salt medium [22] containing standard NOD (11.6 mg/L) in a $10 \mathrm{~mL}$ triangle bottle. The initial $\mathrm{OD}_{600}$ was adjusted to $0.5 \pm 0.02$. The reaction was performed at $30{ }^{\circ} \mathrm{C}$ and $200 \mathrm{r} / \mathrm{min}$. Samples of $300 \mu \mathrm{L}$ for each were taken after $0,24,48,72$, and $96 \mathrm{~h}$, respectively. The control bottle was prepared in the same way without bacterial cells. All samples were centrifuged at $13,000 \mathrm{r} / \mathrm{min}$ for $10 \mathrm{~min}$ and then the concentration of residual NOD in supernatants was determined by HPLC. All experiments were carried out in triplicate.

\subsection{Enzymatic Biodegradation of NOD}

The total biodegradation reaction volume was $5 \mathrm{~mL}$ containing $570 \mathrm{mg} / \mathrm{L}, 380 \mathrm{mg} / \mathrm{L}$, and $211 \mathrm{mg} / \mathrm{L}$ proteins in PBS in each $10 \mathrm{~mL}$ centrifuge tube, respectively. NOD was added to final concentration of $11.6 \mathrm{mg} / \mathrm{L}$ for each. The reaction was performed at $30{ }^{\circ} \mathrm{C}$ and $200 \mathrm{r} / \mathrm{min}$. Samples of $500 \mu \mathrm{L}$ for each were taken after $0,3,6,12,24$, and $36 \mathrm{~h}$, respectively, and then $5 \mu \mathrm{L}$ of concentrated hydrochloric acid $(36 \%, v / v)$ was added to stop the reaction. A control bottle was prepared in the same way without CEs. All samples were centrifuged at 13,000 r/min for $10 \mathrm{~min}$ and then the concentrations of residual NOD and its products in supernatants were analyzed using HPLC. All experiments were carried out in triplicate. 
In order to identify the degradation products of NOD, samples of $1 \mathrm{~mL}$ were passed through a $\mathrm{C}_{18}$ solid-phase extraction cartridge (Waters, Oasis ${ }^{\mathrm{TM}} \mathrm{HLB}$, Milford, MA, USA, $30 \mathrm{mg} / \mathrm{mL}$ ) that had been activated and equilibrated with $1 \mathrm{~mL}$ methanol and $1 \mathrm{~mL}$ water. $1 \mathrm{~mL}$ of water was used to remove impurities and then $1 \mathrm{~mL}$ methanol was used to elute NOD and its products at the rate of $1 \mathrm{~mL} / \mathrm{min}$. The elution was used to measure the mass/charge $(\mathrm{m} / \mathrm{z})$ of NOD and its products with rapid resolution liquid chromatogram-mass spectrum (RRLC-MS).

\subsection{Analysis of NOD and Its Biodegradation Products}

NOD and its enzymatic biodegradation products were firstly analyzed using a HPLC system (Shimadzu LC-10ATVP, Shimadzu Co., Ltd., Kyoto, Japan) with an ultraviolet (UV) Diode Array Detector at $238 \mathrm{~nm}$ using a Agilent TC- $\mathrm{C}_{18}$ column $(4.6 \mathrm{~mm} \times 250 \mathrm{~mm}$ ) (Agilent Technologies Inc., 1200 series, Santa Clara, CA, USA). The mobile phase was water containing $0.05 \%(v / v)$ of trifluoroacetic acid (A) and acetonitrile (B) at a ratio of 65:35 (v/v). The flow rate was $1 \mathrm{~mL} / \mathrm{min}$ and the injection amount was $20 \mu \mathrm{L}$. The concentration of NOD was determined by calibration of peak area (at $238 \mathrm{~nm}$ ) with that of the standard NOD. The biodegradation products that contained Adda were monitored by HPLC based on the assumption that their molar absorption coefficient at $238 \mathrm{~nm}$ is the same as NOD.

Mass spectral analysis of the products were performed using a RRLC-MS. The RRLC system consist of an Agilent 1260 Infinity Binary pump, a 1260 autosampler, and a column compartment (Agilent Technologies Inc., Santa Clara, CA, USA). The detector used was an Agilent 6420 Triple Quadrupole mass spectrometer equipped with an electrospray ionization source operating in positive ionization mode. The analytical column was a ZORBAX Rapid Resolution SB-C $\mathrm{C}_{18}$ column (50 $\mathrm{mm} \times 2.1 \mathrm{~mm}$ i.d., $1.8 \mu \mathrm{m}$, Agilent) maintained at $30^{\circ} \mathrm{C}$. The mobile phase for RRLC-MS analysss was a mixture of water with $0.1 \%$ formic acid and acetonitrile $(40: 60, v / v)$ flowing at $0.4 \mathrm{~mL} / \mathrm{min}$. The injection volume was $5 \mu \mathrm{L}$. The MS detection conditions used were a desolvation gas temperature of $300{ }^{\circ} \mathrm{C}$, desolvation gas flow of $10 \mathrm{~L} / \mathrm{min}$, nebulizer gas $\left(\mathrm{N}_{2}\right)$ pressure of $35 \mathrm{psi}$, and capillary voltage of $4000 \mathrm{~V}$.

Acknowledgments: This work was jointly supported by the National Natural Science Foundation of China (No. 21177009 and 21467009), the Specifical Foundation of Doctoral Program, Ministry of Education, China (No. 20120006110001) and Beijing Municipal Science and Technology Commission (grant number z131102002813058).

Author Contributions: Hai Yan conceived and designed the experiments; Nan Feng and Fan Yang performed the experiments, analyzed the data and wrote the paper; Chunhua Yin, Xiaolu Liu, Haiyang Zhang, Qianqian Xu, Le Lv and Huasheng Wang contributed reagents/materials/analysis tools.

Conflicts of Interest: The authors declare no conflict of interest.

\section{References}

1. Svrcek, C.; Smith, D.W. Cyanobacteria toxins and the current state of knowledge on water treatment options: A review. J. Environ. Eng. Sci. 2004, 3, 155-185. [CrossRef]

2. Repka, S.; Meyerhofer, M.; von Brockel, K.; Sivonen, K. Associations of cyanobacterial toxin, nodularin, with environmental factors and zooplankton in the Baltic Sea. Microb. Ecol. 2004, 47, 350-358. [CrossRef] [PubMed]

3. Heresztyn, T.; Nicholson, B.C. Nodularin concentrations in Lakes Alexandrina and Albert, South Australia, during a bloom of the cyanobacterium (blue-green alga) Nodularia spumigena and degradation of the toxin. Environ. Toxicol. Water Qual. 1997, 12, 273-282. [CrossRef]

4. Horne, A.J.; Galat, D.L. Nitrogen fixation in an oligotrophic, saline desert lake: Pyramid Lake, Nevada. Limnol. Oceanogr. 1985, 30, 1229-1239. [CrossRef]

5. Nehring, S. Mortality of dogs associated with a mass development of Nodularia spumigena (Cyanophyceae) in a brackish lake at the German North Sea coast. J. Plankton Res. 1993, 15, 867-872. [CrossRef]

6. Beattie, K.A.; Kaya, K.; Codd, G.A. The cyanobacterium Nodularia PCC 7804, of freshwater origin, produces [L-Har2] nodularin. Phytochemistry 2000, 54, 57-61. [CrossRef] 
7. Rinehart, K.L.; Harada, K.; Namikoshi, M.; Chen, C.; Harvis, C.A.; Munro, M.H.G.; Blunt, J.W.; Mulligan, P.E.; Beasley, V.R.; Al, E. Nodularin, microcystin, and the configuration of Adda. J. Am. Chem. Soc. 1988, 110. [CrossRef]

8. Ohta, T.; Sueoka, E.; Iida, N.; Komori, A.; Suganuma, M.; Nishiwaki, R.; Tatematsu, M.; Kim, S.J.; Carmichael, W.W.; Fujiki, H. Nodularin, a potent inhibitor of protein phosphatases 1 and 2A, is a new environmental carcinogen in male F344 rat liver. Cancer Res. 1994, 54, 6402-6406. [PubMed]

9. Carmichael, W.W.; Eschedor, J.T.; Patterson, G.M.; Moore, R.E. Toxicity and partial structure of a hepatotoxic peptide produced by the cyanobacterium Nodularia spumigena Mertens emend. L575 from New Zealand. Appl. Environ. Microbiol. 1988, 54, 2257-2263. [PubMed]

10. Codd, G.A.; Bell, S.G.; Kaya, K.; Ward, C.J.; Tie, K.A.; Metcalf, J.S. Cyanobacteria toxins, exposure routes and human health. Eur. J. Phycol. 1999, 34, 405-415. [CrossRef]

11. Stewart, I.; Seawright, A.A.; Shaw, G.R. Cyanobacterial poisoning in livestock, wild mammals and birds-An overview. In Cyanobacterial Harmful Algal Blooms: State of the Science and Research Needs; Hudnell, H.K., Ed.; Publisher: New York, NY, USA, 2008; Volume 619, pp. 613-637.

12. Van, H.A.; Harding, W.R.; Wessels, J.C.; Schneider, D.J.; Heine, E.W.; Van, D.M.J.; Fourie, J.M. Cyanobacterial (blue-green algae) poisoning of livestock in the western Cape Province of South Africa. J. S. Afr. Vet. Assoc. 1995, 66, 260-264.

13. Pearson, L.; Mihali, T.; Moffitt, M.; Kellmann, R.; Neilan, B. On the chemistry, toxicology and genetics of the cyanobacterial toxins, microcystin, nodularin, saxitoxin and cylindrospermopsin. Mar. Drugs 2010, 8, 1650-1680. [CrossRef] [PubMed]

14. Annila, A.; Lehtimaki, J.; Mattila, K.; Eriksson, J.E.; Sivonen, K.; Rantala, T.T.; Drakenberg, T. Solution structure of nodularin. An inhibitor of serine/threonine-specific protein phosphatases. J. Biol. Chem. 1996, 271, 16695-16702. [PubMed]

15. Merel, S.; Clement, M.; Thomas, O. State of the art on cyanotoxins in water and their behaviour towards chlorine. Toxicon 2010, 55, 677-691. [CrossRef] [PubMed]

16. Rapala, J.; Berg, K.A.; Lyra, C.; Niemi, R.M.; Manz, W.; Suomalainen, S.; Paulin, L.; Lahti, K. Paucibacter toxinivorans gen. nov., sp nov., a bacterium that degrades cyclic cyanobacterial hepatotoxins microcystins and nodularin. Int. J. Syst. Evol. Microbiol. 2005, 55, 1563-1568. [CrossRef] [PubMed]

17. Imanishi, S.; Kato, H.; Mizuno, M.; Tsuji, K.; Harada, K. Bacterial degradation of microcystins and nodularin. Chem. Res. Toxicol. 2005, 18, 591-598. [CrossRef] [PubMed]

18. Lawton, L.A.; Welgamage, A.; Manage, P.M.; Edwards, C. Novel bacterial strains for the removal of microcystins from drinking water. Water Sci. Technol. 2011, 63, 1137-1142. [CrossRef] [PubMed]

19. Bourne, D.G.; Jones, G.J.; Blakeley, R.L.; Jones, A.; Negri, A.P.; Riddles, P. Enzymatic pathway for the bacterial degradation of the cyanobacterial cyclic peptide toxin microcystin LR. Appl. Environ. Microbiol. 1996, 62, 4086-4094. [PubMed]

20. Hai, Y.; Wang, H.; Wang, J.; Yin, C.; Song, M.; Liu, X.; Yin, X. Cloning and expression of the first gene for biodegrading microcystin LR by Sphingopyxis sp. USTB-05. J. Environ. Sci. 2012, 10, 1816-1822.

21. Shimizu, K.; Maseda, H.; Okano, K.; Kurashima, T.; Kawauchi, Y.; Qiang, X.; Utsumi, M.; Zhang, Z.; Sugiura, N. Enzymatic pathway for biodegrading microcystin LR in Sphingopyxis sp. C-1. J. Biosci. Bioeng. 2012, 114, 630-634. [CrossRef] [PubMed]

22. Wang, J.; Wu, P.; Chen, J.; Yan, H. Biodegradation of microcystin-RR by a new isolated Sphingopyxis sp. USTB-05. Chin. J. Chem. Eng. 2010, 18, 108-112. [CrossRef]

23. Xiao, C.; Yan, H.; Wang, J.; Wei, W.; Ning, J.; Pan, G. Microcystin-LR biodegradation by Sphingopyxis sp. USTB-05. Front. Environ. Sci. Eng. China 2011, 5, 526-532. [CrossRef]

24. Xu, H.; Wang, H.; Xu, Q.; Lv, L.; Yin, C.; Liu, X.; Du, H.; Yan, H. Pathway for Biodegrading Microcystin-YR by Sphingopyxis sp. USTB-05. PLoS ONE 2015, 10. [CrossRef] [PubMed]

25. Namikoshi, M.; Rinehart, K.L.; Sakai, R.; Stotts, R.R.; Dahlem, A.M.; Beasley, V.R.; Carmichael, W.W.; Evans, W.R. Identification of 12 hepatotoxins from a Homer Lake bloom of the cyanobacteria Microcystis aeruginosa, Microcystis viridis, and Microcystis wesenbergii: Nine new microcystins. J. Organ. Chem. 1992, 57. [CrossRef]

26. Mazur-Marzec, H.; Torunska, A.; Blonska, M.J.; Moskot, M.; Plinski, M.; Jakobkiewicz-Banecka, J.; Wegrzyn, G. Biodegradation of nodularin and effects of the toxin on bacterial isolates from the Gulf of Gdansk. Water Res. 2009, 43, 2801-2810. [CrossRef] [PubMed] 
27. Torunska, A.; Bolalek, J.; Plinski, M.; Mazur-Marzec, H. Biodegradation and sorption of nodularin (NOD) in fine-grained sediments. Chemosphere 2008, 70, 2039-2046. [CrossRef] [PubMed]

28. Holst, T.; Jorgensen, N.O.G.; Jorgensen, C.; Johansen, A. Degradation of microcystin in sediments at oxic and anoxic, denitrifying conditions. Water Res. 2003, 37, 4748-4760. [CrossRef]

29. Saitou, T.; Sugiura, N.; Itayama, T.; Inamori, Y.; Matsumura, M. Degradation characteristics of microcystins by isolated bacteria from Lake Kasumigaura. J. Water Supply Res. Technol. AQUA 2003, 52, 13-18.

30. Yang, F.; Zhou, Y.; Sun, R.; Wei, H.; Li, Y.; Yin, L.; Pu, Y. Biodegradation of microcystin-LR and-RR by a novel microcystin-degrading bacterium isolated from Lake Taihu. Biodegradation 2014, 25, 447-457. [CrossRef] [PubMed]

31. Edwards, C.; Graham, D.; Fowler, N.; Lawton, L.A. Biodegradation of microcystins and nodularin in freshwaters. Chemosphere 2008, 73, 1315-1321. [CrossRef] [PubMed]

32. Kato, H.; Imanishi, S.Y.; Tsuji, K.; Harada, K.-I. Microbial degradation of cyanobacterial cyclic peptides. Water Res. 2007, 41, 1754-1762. [CrossRef] [PubMed]

33. Ishii, H.; Nishijima, M.; Abe, T. Characterization of degradation process of cyanobacterial hepatotoxins by a gram-negative aerobic bacterium. Water Res. 2004, 38, 2667-2676. [CrossRef] [PubMed]

34. Wang, H.; Yan, H.; Ma, S.; Liu, X.; Yin, C.; Wang, H.; Xu, Q.; Lv, L. Characterization of the second and third steps in the enzymatic pathway for microcystin-RR biodegradation by Sphingopyxis sp. USTB-05. Ann. Microbiol. 2015, 65, 495-502. [CrossRef]

35. Yan, H.; Wang, J.; Chen, J.; Wei, W.; Wang, H.; Wang, H. Characterization of the first step involved in enzymatic pathway for microcystin-RR biodegraded by Sphingopyxis sp. USTB-05. Chemosphere 2012, 87, 12-18. [CrossRef] [PubMed]

(C) 2016 by the authors; licensee MDPI, Basel, Switzerland. This article is an open access article distributed under the terms and conditions of the Creative Commons Attribution (CC-BY) license (http:/ / creativecommons.org/licenses/by/4.0/). 